\title{
Promising unconventional plant raw materials for food production
}

\author{
Elena Belokurova ${ }^{1 *}$, Anna Derkanosova ${ }^{1}$, Yana Dombrovskaya ${ }^{1}$, and Tatyana Malyutina ${ }^{1}$ \\ ${ }^{1}$ Voronezh State University of Engineering Technologies, Voronezh, Russia
}

\begin{abstract}
Article contains information about new technologies of flour and bakery products on the basis of multicomponent structure products or the flour composite mixes executed from a flour of pumpkin and a thistle, a dry leaf of a stevia and dry lactulose, and also mixes from different types of grain, such as: corn, buckwheat, rice, millet.
\end{abstract}

\section{Introduction}

Due to the fact that flour confectionery products are popular among the population, due to their attractive appearance and high taste qualities, for domestic producers the scientific and technical problem is the creation of highly effective technologies, expanding the range of products, the development of original formulas, creating functional products, improving consumer properties and nutritional value, improving their structure.

The use of ready-made concentrates with the introduction of biologically active raw materials, products of multicomponent composition, which were named flour composite mixtures (FCM), is one of the priority directions for solving these problems [1].

Powder components such as pumpkin and thistle flour, dry stevia leaf and dry lactulose were considered to create a new generation of products based on FCM. Although additives in a dry form remain in the natural biological environment for a long time, when enriching FCM it is necessary to maintain stability in the quality of the components until the system needs to be converted to an aquatic composition.

The FCM under consideration are thermophiles, and pumpkin meal is a rich source of complete and easily digestible vegetable protein, its content reaches $40 \%$. The high biological and nutritional value of pumpkin meal is largely due to its unique mineral composition [1].

\section{Experimental}

Thistle flour is useful to eat regularly for prevention and as part of the complex treatment of atherosclerosis, varicose veins, coronary heart disease, arterial hypertension, inflammatory heart disease and blood vessels, as it is present in its composition: proteins, mono- and dysaccharides, flavonoids and flavolignans (silybin, silichristine, silidianine, taxifolin, neohydrocarpine, quercetin, etc.), carotenoids, vitamins E, K, D, vitamins of group B, chlorophyll, essential oil
(0.08\%), resins, mucus, biogenic amines (histamine, tyramine), enzymes, alkaloids, bitterness, saponins, as well as various macro- and microelements (magnesium, potassium, manganese, calcium, iron, zinc, selenium, chrome, copper, aluminum, boron, vanadium, etc.).

It was found that lactulose both separately and in combination with bifidobacteria promotes the absorption of calcium and increases the strength of bones in osteoporosis, it is classified as oligosaccharides. Lactulose is a white crystalline substance, odourless, sweet to the taste and well soluble in water.

Stevia leaves contain mineral compounds, organic substances, vitamins A, C, E, P; flavonoids, essential oils, amino acids, pectins, sterebins. This valuable set of chemical compounds helps to rationalize the process of hormone synthesis in the human body, which allows: provide tissue respiration, normalize the work of enzyme systems, reduce cholesterol, restore carbohydrate-proteinlipid metabolism, stabilize blood pressure, stimulate digestion and urinary system [2].

The results of research of products manufactured on the basis of FCM with introduction of biologically active raw materials are presented in Tables 1,2 .

The mass fraction of the moisture of the raw materials used is shown in Table 3.

Table 1. Comparative assessment of sample viscosity

\begin{tabular}{|c|c|c|c|c|c|c|c|}
\hline Indicator & Control & $\begin{array}{c}\text { Lactulose } \\
\text { content of } \\
\text { samples in } \\
\text { relation to } \\
\text { to the } \\
\text { FCM, \% }\end{array}$ & $\begin{array}{c}\text { Pumpkin } \\
\text { seed flour } \\
\text { content in } \\
\text { samples } \\
\text { at to } \\
\text { to the FCM, } \\
\%\end{array}$ & $\begin{array}{c}\text { Contents } \\
\text { thistle flours in } \\
\text { reference to } \\
\text { to the FCM, } \\
\%\end{array}$ \\
\cline { 2 - 8 } & 0.8 & 1.1 & 13.5 & 15.0 & 11.0 & 13.0 \\
\hline $\begin{array}{c}\text { Viscosity, } \\
\text { Pa.s }\end{array}$ & 4.5 & 4.0 & 3.3 & 4.5 & 6.0 & 3.9 & 6.8 \\
\hline
\end{tabular}


Table 2. Comparative moisture assessment of samples

\begin{tabular}{|c|c|c|c|c|c|c|c|}
\hline \multirow{2}{*}{ Indicators } & Control & \multicolumn{2}{|c|}{$\begin{array}{c}\text { Lactulose content of samples } \\
\text { in relation to } \\
\text { to the FCM, \% }\end{array}$} & $\begin{array}{c}\text { Pumpkin seed flour content } \\
\text { of samples in relation to } \\
\text { to the FCM, \% }\end{array}$ & \multicolumn{2}{|c|}{$\begin{array}{c}\text { Thistle flour content of } \\
\text { samples in relation to } \\
\text { to the FCM, \% }\end{array}$} \\
\cline { 3 - 8 } & & 0.8 & 1.1 & 13.5 & 15.0 & 11.0 & 13.0 \\
\hline Humidity (dough),\% & 28.7 & 28.9 & 36.4 & 28.0 & 33.6 & 27.0 & 32.6 \\
\hline Humidity (crumb), \% & 26.1 & 22.3 & 29.2 & 25.4 & 28.4 & 25.4 & 28.7 \\
\hline
\end{tabular}

Table 3. Mass fraction of moisture of applied vegetable raw materials

\begin{tabular}{|c|c|}
\hline Product name & Mass fraction of moisture, $\%$ \\
\hline Verona Concentrate & 5.3 \\
\hline Pumpkin flour & 5.5 \\
\hline Thistle flour & 4.7 \\
\hline Lactulose & 6.8 \\
\hline $\begin{array}{c}\text { Stevia leaf (variety in } \\
\text { vintro) }\end{array}$ & 7.2 \\
\hline
\end{tabular}

\section{Results and discussion}

The proposed types of plant raw materials have high antioxidant activity, which will give the products based on them functional properties (Table 4).

As a result of the conducted researches technical and technological cards for flour products with the content of dry leaf stevia and biologically active raw materials were developed and introduced into production: TTK on "Lactulose sponge" with the content of dry lactulose $0.8 \%$ to FCM mass; TTK on "Pumpkin sponge" with the content of pumpkin flour $13.5 \%$ to FCM mass; TTK on "Spiky sponge" with the content of $11 \%$ to FCM mass.

The next stage of the study was the development of new bakery products, the formulation of which is introduced flour from different cereals to replace part of wheat flour, which allows to balance products on the qualitative and quantitative composition of protein, as well as increase the content of dietary fiber, vitamins and trace elements to the recommended consumption rates. This allows you to manage the chemical composition and biological value of products, while changing their organoleptic characteristics: taste, aroma, appearance, which allows you to expand the range of products.

Table 4. Antioxidant activity of the investigated samples

\begin{tabular}{|c|c|c|c|}
\hline $\begin{array}{c}\text { № } \\
\text { sample }\end{array}$ & \multicolumn{2}{|l|}{ Sample name } & $\begin{array}{c}\text { Content of } \\
\text { antioxidants, } \\
\mathrm{mg} / \mathrm{g}\end{array}$ \\
\hline 1 & \multicolumn{2}{|l|}{ Biscuit based on FCM } & 0.008 \\
\hline 2 & \multicolumn{2}{|l|}{$\begin{array}{l}\text { Biscuit to traditional technologies } \\
\text { (control) }\end{array}$} & 0.013 \\
\hline 3 & \multicolumn{2}{|l|}{$\begin{array}{c}\text { Stevia leaf } \\
\end{array}$} & 0.110 \\
\hline 4 & \multirow[t]{2}{*}{ Biscuit with lactulose content, $\%$} & 0.8 & 0.038 \\
\hline 5 & & 11 & 0.045 \\
\hline 6 & \multirow[t]{2}{*}{ Biscuit with pumpkin flour, $\%$} & 135 & 0.033 \\
\hline 7 & & 15.0 & 0.043 \\
\hline 8 & \multicolumn{2}{|l|}{ Pumpkin flour } & 0.026 \\
\hline 9 & \multirow{2}{*}{\multicolumn{2}{|c|}{\begin{tabular}{|l|l|} 
Biscuit containing thistle flour, $\%$ & 11.0 \\
& 13.0 \\
\end{tabular}}} & 0.130 \\
\hline 10 & & & 0.142 \\
\hline 11 & \multicolumn{2}{|l|}{ Thistle flour } & 0.191 \\
\hline
\end{tabular}

When assessing the quality, bakery products cooked according to a classical recipe were taken for control; prototypes were prepared according to a similar recipe with the replacement of a part of wheat flour of the highest grade by a selected mixture; the recipe and technological modes of dough testing are given in Table 6.

In the process of fermentation of the dough every 30 minutes physical-chemical and structural-mechanical parameters were determined, as a result of a number of studies the best samples were recognized with the introduction of mixtures 2, 4, 5 into the recipe.

For these products there was carried out the qualification evaluation of quality, which provides the evaluation of the totality of organoleptic, physicochemical and structural-mechanical parameters of products. The evaluation of product quality levels provides the definition of values of quality indicators of the evaluated products and their comparison with the basic ones [4]. Thus the concept of relative value of the indicator of quality of production qi which is defined by a differential method is used. Its essence consists in separate comparison of unit quality indicators of the considered product with similar basic indicators. For this purpose the relative quality index was defined by the formula:

$$
q_{i}=p_{i} / p_{a}
$$

where $p_{i}, p_{a}-$ is the value of the $i$-th quality index for the evaluated and base samples respectively.

The comprehensive quality assessment involves the use of comprehensive property set indicators, which must take into account the significance of each property, i.e. assess the extent to which individual property values influence the final quality indicator. Each individual quality index is characterised by two parameters - the relative index and the weighting. When determining the weighting factors, the main criteria are identified, which most fully reflect the ability of the product to fulfil its primary purpose. In this case, the traditional point scales used in the current standards are taken into account [5]. The quality indicators of bakery products, on the basis of which the qualification evaluation was carried out, are given in Table 7.

The values of complex quality indicators of the examined samples of bakery products are given in Table 8 .

From the obtained data, we determined a generalized complex quality indicator, which was: for control - 1.0; sample 2-1.2; sample 4-1.18; sample 5 -1.12 . The appearance of samples of received bakery products is shown in Fig. 1. 
Table 5. Ratio of components of selected mixtures, \%

\begin{tabular}{|c|c|c|c|c|}
\hline \multirow{2}{*}{$\begin{array}{c}\text { Blend } \\
\text { number }\end{array}$} & \multicolumn{4}{|c|}{ Ratio of mixture components, \% } \\
\cline { 2 - 5 } & Corn & $\begin{array}{c}\text { Buckwheat } \\
\text { flour }\end{array}$ & Rice flour & Wheat flour \\
\hline 1 & 39 & 33 & 20 & 8 \\
\hline 2 & 40 & 32 & 20 & 8 \\
\hline 3 & 41 & 31 & 20 & 8 \\
\hline 4 & 42 & 30 & 20 & 8 \\
\hline 5 & 47 & 25 & 20 & 8 \\
\hline
\end{tabular}

Table 6. Recipe and modes of dough testing process

\begin{tabular}{|c|c|}
\hline $\begin{array}{l}\text { Name of raw materials, } \\
\text { semi-finished goods and } \\
\text { process indicators }\end{array}$ & $\begin{array}{l}\text { Raw material consumption } \\
\text { and process parameters }\end{array}$ \\
\hline $\begin{array}{l}\text { Wheat flour bakery top grade, } \\
\text { kg }\end{array}$ & $88-94 *$ \\
\hline Bakery yeast extruded, kg & 1.5 \\
\hline Food salt, kg & 1.3 \\
\hline Composite blend, kg & $6-12 * *$ \\
\hline Water, kg & by calculation \\
\hline Initial temperature, ${ }^{\circ} \mathrm{C}$ & 27.0 \\
\hline Duration fermentation, $\min$ & 180.0 \\
\hline $\begin{array}{l}\text { The acidity is final, hail, no } \\
\text { more than }\end{array}$ & 4.0 \\
\hline
\end{tabular}

Table 7. Quality indicators of bakery products

\begin{tabular}{|c|c|c|c|c|}
\hline \multirow{2}{*}{ Indicator } & \multicolumn{4}{|c|}{ The value of the quality indicator } \\
\cline { 2 - 5 } & Control & $\begin{array}{c}\text { Sample } \\
2\end{array}$ & $\begin{array}{c}\text { Sample } \\
4\end{array}$ & Sample 5 \\
\hline Organoleptic & \multicolumn{4}{|l|}{} \\
\hline Appearance, score & 4 & 5 & 5 & 4 \\
\hline Form, score & 4 & 5 & 5 & 4 \\
\hline Crust color, score & 4 & 5 & 5 & 5 \\
\hline Bakery, point & 5 & 5 & 5 & 5 \\
\hline Promise, point & 5 & 5 & 5 & 5 \\
\hline Taste, score & 3 & 5 & 5 & 4 \\
\hline Smell, score & 3 & 5 & 5 & 4 \\
\hline Physico-chemical & & & & \\
\hline Humidity, \% & 42,8 & 42,2 & 42,5 & 44,2 \\
\hline Acidity, hail & 3,0 & 3,2 & 3,2 & 3,0 \\
\hline Porosity, \% & 73,0 & 76,0 & 74,0 & 72,0 \\
\hline $\begin{array}{c}\text { Specific volume } \\
\text { cm }{ }^{3} / 100 \text { g }\end{array}$ & 324,0 & 350,0 & 342,0 & 330,0 \\
\hline $\begin{array}{c}\text { Structural and } \\
\text { mechanical }\end{array}$ & 60,0 & 65,5 & 65,0 & 60,0 \\
\hline $\begin{array}{c}\text { General deformation of } \\
\text { crumb compression, etc }\end{array}$ & 60,0 & 65,5 & 65,0 & 60,0 \\
\hline
\end{tabular}

Table 8. Complex indicators of product quality by studied properties

\begin{tabular}{|c|c|c|c|}
\hline \multirow{2}{*}{ Sample product } & \multicolumn{3}{|c|}{ Value of complex quality parameters } \\
\cline { 2 - 4 } & Organoleptic & $\begin{array}{c}\text { Physico- } \\
\text { chemical }\end{array}$ & $\begin{array}{c}\text { structural- } \\
\text { mechanical }\end{array}$ \\
\hline Control & 1.00 & 1.00 & 1.00 \\
\hline Sample 2 & 1.31 & 1.20 & 1.09 \\
\hline Sample 4 & 1.28 & 1.19 & 1.08 \\
\hline Sample 5 & 1.23 & 1.12 & 1.00 \\
\hline
\end{tabular}
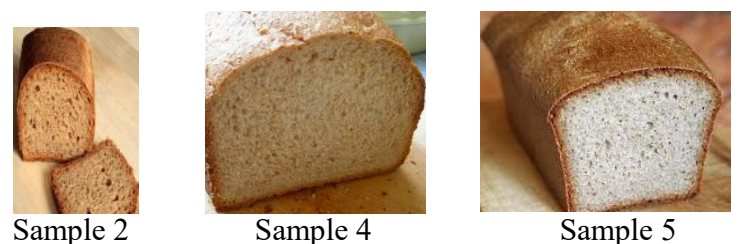

Fig. 1. Samples of bakery products

\section{Conclusion}

Thus, the use of such valuable plant raw materials as pumpkin and thistle flour, dry stevia leaf, dry lactulose, as well as flour from mixtures of corn, buckwheat, rice, millet in the formulation composition of flour confectionery and bakery products will expand the range of confectionery and bakery products, enrich them with useful functional ingredients, give functional orientation. Products on the proposed technology will be in demand among the population, as they have high taste qualities, improved nutritional value. These products can be recommended for feeding different groups of the population, including children of primary and school age.

\section{References}

1. E.V. Belokurova and A.A. Derkanosova, Bulletin of VSUET, 2, 119-124 (2013)

2. Ya.P. Kolomnikova, A.A. Derkanosova, and E.V. Litvinova, Economics. Innovation Quality control, 2 (11), 139-143 (2015)

3. E.V. Belokurova, T.N. Malyutina, and N.M. Derkanosova, "Influence of the hop extract on the infecting microflora of rye starches". Collection of Articles of the VIII International Scientific and Technical Conference dedicated to the 90th anniversary of the Faculty of Technology VGUIT, 2019, Voronezh.

4. E.V. Belokurova, S.A. Solokhin, and A.A. Rodionov, Technologies of food and processing industry of agro-industrial complex - Healthy food products, 3 (11), 51-55, (2016)

5. S.V. Belokurov, N.S. Rodionova, E.V Belokurova., and T.V. Alexeeva, Journal of Physics: Conference Series (see books), 1015, 1-4 (2018) 